\title{
Changes in Properties of Auditory Nerve Synapses following Conductive Hearing Loss
}

\author{
Xiaowen Zhuang, ${ }^{1}$ Wei Sun, ${ }^{2}$ and Matthew A. Xu-Friedman ${ }^{1}$ \\ ${ }^{1}$ Department of Biological Sciences, University at Buffalo, State University of New York, Buffalo, New York 14260, and ${ }^{2}$ Center for Hearing and Deafness, \\ Department of Communicative Disorders and Sciences, University at Buffalo, State University of New York, Buffalo, New York 14260
}

Auditory activity plays an important role in the development of the auditory system. Decreased activity can result from conductive hearing loss (CHL) associated with otitis media, which may lead to long-term perceptual deficits. The effects of CHL have been mainly studied at later stages of the auditory pathway, but early stages remain less examined. However, changes in early stages could be important because they would affect how information about sounds is conveyed to higher-order areas for further processing and localization. We examined the effects of $\mathrm{CHL}$ at auditory nerve synapses onto bushy cells in the mouse anteroventral cochlear nucleus following occlusion of the ear canal. These synapses, called endbulbs of Held, normally show strong depression in voltage-clamp recordings in brain slices. After 1 week of CHL, endbulbs showed even greater depression, reflecting higher release probability. We observed no differences in quantal size between control and occluded mice. We confirmed these observations using mean-variance analysis and the integration method, which also revealed that the number of release sites decreased after occlusion. Consistent with this, synaptic puncta immunopositive for VGLUT1 decreased in area after occlusion. The level of depression and number of release sites both showed recovery after returning to normal conditions. Finally, bushy cells fired fewer action potentials in response to evoked synaptic activity after occlusion, likely because of increased depression and decreased input resistance. These effects appear to reflect a homeostatic, adaptive response of auditory nerve synapses to reduced activity. These effects may have important implications for perceptual changes following CHL.

Key words: conductive hearing loss; endbulbs of Held; release probability; release sites; synaptic transmission

\section{Significance Statement}

Normal hearing is important to everyday life, but abnormal auditory experience during development can lead to processing disorders. For example, otitis media reduces sound to the ear, which can cause long-lasting deficits in language skills and verbal production, but the location of the problem is unknown. Here, we show that occluding the ear causes synapses at the very first stage of the auditory pathway to modify their properties, by decreasing in size and increasing the likelihood of releasing neurotransmitter. This causes synapses to deplete faster, which reduces fidelity at central targets of the auditory nerve, which could affect perception. Temporary hearing loss could cause similar changes at later stages of the auditory pathway, which could contribute to disorders in behavior.

\section{Introduction}

Auditory experience can cause changes in nervous system function, which may have adaptive, but also pathological, impacts (Kopp-Scheinpflug and Tempel, 2015). Processing disorders can

\footnotetext{
Received Feb. 16, 2016; revised Nov. 10, 2016; accepted Nov. 19, 2016.

Author contributions: M.A.X.-F. and X.W.Z. designed research; X.W.Z. performed research; W.S. contributed unpublished reagents/analytic tools; X.W.Z. and M.A.X.-F. analyzed data; X.W.Z. and M.A.X.-F. wrote the paper.

This work was supported by National Science Foundation Grant 1208131 to M.A.X.-F. We thank H. Yang, Y. Yang,

T. Ngodup, N. Wong, and G. Si for helpful comments on the manuscript.

The authors declare no competing financial interests.

Correspondence should be addressed to Dr. Matthew A. Xu-Friedman, Department of Biological Sciences, University at Buffalo, State University of New York, Buffalo, NY 14260. E-mail: mx@buffalo.edu.

DOI:10.1523/JNEUROSCI.0523-16.2016

Copyright $\odot 2017$ the authors $\quad 0270-6474 / 17 / 370323-10 \$ 15.00 / 0$
}

result from otitis media (OM), which is common during childhood (Holm and Kunze, 1969; Gravel et al., 2006). It has been suggested that the primary risk factor is actually the degree of conductive hearing loss (CHL), rather than status of OM itself (Gravel and Wallace, 2000; Whitton and Polley, 2011). However, it is not known how reduction in auditory activity causes deficits, nor what the cellular origin of deficits is.

Most studies of the effects of CHL have focused on high-order neurons, such as those in the inferior colliculus or auditory cortex (Wang et al., 2002; Xu et al., 2007; Popescu and Polley, 2010; Takesian et al., 2010; de Villers-Sidani and Merzenich, 2011). However, it is important to understand the effects of experience on early parts of the auditory pathway because they could partially underlie changes observed at later levels. Furthermore, changes in early cells and syn- 
apses could be magnified in downstream auditory processing, and thereby lead to disorders in behavior.

One important early stage is the anteroventral cochlear nucleus (AVCN). Within the AVCN, auditory nerve fibers terminate on bushy cells (BCs), forming large and powerful synapses called "endbulbs of Held" (Lorente de Nó, 1981; Ryugo and Fekete, 1982). BCs relay precise timing information from the auditory nerve to brain areas involved in sound localization (Smith et al., 1993; Oertel, 1999; Cant and Benson, 2003).

Some studies have examined the effects of reduced activity on endbulbs, by using strains of mice that are congenitally deaf, have early-onset hearing loss, or carry mutations in proteins important to cochlear or synaptic function (Oleskevich and Walmsley, 2002; Wang and Manis, 2005; Mendoza Schulz et al., 2014; Wright et al., 2014). There is also extensive work studying multiple deafening approaches in the chick (Tucci and Rubel, 1985; Tucci et al., 1987; Kuba et al., 2010, 2014). These deafness models have been linked to synaptic changes in release probability $\left(P_{\mathrm{r}}\right)$, quantal size $(Q)$, the size of the readily releasable pool of vesicles $(N)$, and general synaptic morphology, which is likely related to $N$. Different models can have different results, which has made it difficult to determine whether these changes are caused by auditory nerve activity, by a direct effect of the mutated protein, or by nonspecific differences in mouse strains on synaptic transmission. For example, age-related deafness led to decreased $Q$ and $P_{\mathrm{r}}$ (Wang and Manis, 2005), whereas mutation of the presynaptic scaffold bassoon, which also causes hearing loss, resulted in increased $Q$ and $P_{\mathrm{r}}$ (Mendoza Schulz et al., 2014). Changes in $Q$ are suggestive of synaptic scaling, which is a well-established form of activity-dependent homeostasis (O'Brien et al., 1998; Turrigiano et al., 1998; Turrigiano and Nelson, 2004; Keck et al., 2013). However, the opposite effects of these two manipulations on $P_{\mathrm{r}}$ and $Q$ are difficult to reconcile.

To address such issues, we used a milder and reversible manipulation to reduce auditory activity, bilateral occlusion of the ear canal. We examined presynaptic and postsynaptic changes after occlusion using electrophysiology and immunohistochemistry at endbulbs of Held. Endbulbs showed more depression after occlusion, and partially recovered after returning to normal conditions. There was no change in quantal size $(Q)$, but a decrease in the number of release sites $(N)$. In addition, occlusion led to lower firing probability in BCs. These effects suggest the existence of a homeostatic and adaptive mechanism to optimize the efficiency of synapses during low activity. These effects may be important for understanding how CHL induces changes at the very first stage of the auditory system.

\section{Materials and Methods}

All experiments were performed with the approval of the University at Buffalo's Institutional Animal Care and Use Committee. Experimental subjects were $\mathrm{CBA} / \mathrm{CaJ}$ mice of either sex, ranging in age from postnatal day 15 (P15) to P33.

Bilateral ear occlusion. Ears were bilaterally occluded by injecting a small volume of silicone elastomer (Kwik-Cast, WPI) into the auditory canal or by ligating the auditory canal at P14 (Popescu and Polley, 2010). Mice were anesthetized with $200 \mathrm{mg} / \mathrm{kg}$ ketamine plus $10 \mathrm{mg} / \mathrm{kg}$ xylazine. An incision was made beside the pinna, and a portion of the ear canal was exposed and ligated with surgical silk (Harvard Apparatus). The incision was closed using suturing and Vetbond. Mice were restored to their home cages until brain slice electrophysiology recordings. In a subset of mice, ears were ligated at P21 and the ligatures were removed at P24.

Auditory brainstem responses (ABRs). ABRs were recorded to assess hearing thresholds after ear occlusion and after ear occlusion removal. Mice were anesthetized with $200 \mathrm{mg} / \mathrm{kg}$ ketamine plus $10 \mathrm{mg} / \mathrm{kg}$ xylazine.
ABRs were recorded with a vertex electrode, an electrode inserted behind the pinna ipsilateral to the stimulated ear, and a ground electrode inserted contralateral to the stimulated ear. Clicks $(100 \mu \mathrm{s})$ were presented through a speaker placed into the ear canal. ABR threshold was obtained for each animal by reducing the stimulus intensity in $10 \mathrm{~dB}$ steps and then $5 \mathrm{~dB}$ steps to identify the lowest intensity that elicited a response. ABRs were recorded in a sound-proof room with auditory-evoked response averaging system controlled by TDT software (BioSig) (Sun et al., 2009).

Brain slice electrophysiology. Parasagittal slices of AVCN were cut from the auditory brainstem of P15-P33 mice as described previously (Yang and Xu-Friedman, 2008; Yang and Xu-Friedman, 2015). Briefly, slices $(142 \mu \mathrm{m})$ were cut in an ice-cold sucrose-based solution containing the following (in mM): $76 \mathrm{NaCl}, 75$ sucrose, $25 \mathrm{NaHCO}_{3}, 25$ glucose, $2.5 \mathrm{KCl}$, $1.25 \mathrm{NaH}_{2} \mathrm{PO}_{4}, 7 \mathrm{MgCl}_{2}$, and $0.5 \mathrm{CaCl}_{2}$. Then slices were transferred and incubated at $30^{\circ} \mathrm{C}$ for $20 \mathrm{~min}$ in standard recording solution containing the following (in mM): $125 \mathrm{NaCl}, 26 \mathrm{NaHCO}_{3}, 2.5 \mathrm{KCl}, 1.25 \mathrm{NaH}_{2} \mathrm{PO}_{4}$, 20 glucose, $1.5 \mathrm{CaCl}_{2}, 1 \mathrm{MgCl}_{2}, 4 \mathrm{Na}$-L-lactate, $2 \mathrm{Na}$-pyruvate, $0.4 \mathrm{Na}$-Lascorbate, bubbled with $95 \% \mathrm{O}_{2} / 5 \% \mathrm{CO}_{2}$. Slices were then maintained at room temperature until recording. Mean-variance analysis experiments were conducted in different external calcium concentrations $\left(\mathrm{Ca}_{\mathrm{e}}\right)$ by replacing 1.5:1.0 $\mathrm{CaCl}_{2}: \mathrm{MgCl}_{2}$ with 3:0 or 1:1.5 $\mathrm{CaCl}_{2}: \mathrm{MgCl}_{2}$. Strychnine $(5 \mu \mathrm{M})$ was present during all recordings to block spontaneous glycinergic IPSCs. TTX was not used because blocking action potentials is unnecessary for measuring endbulb mEPSCs. Action potential-evoked EPSCs are easily distinguished from spontaneous quantal release because of the $>10$-fold difference in amplitude, and auditory nerve fibers do not fire spikes without electrical stimulation. Thus, all small spontaneous synaptic currents reflect quantal release.

BCs were patched under an Olympus BX51WI microscope with a Multiclamp 700B (Molecular Devices) controlled by an ITC-18 interface (Instrutech), driven by custom-written software (mafPC) running in Igor (WaveMetrics). The bath was perfused at 3-4 $\mathrm{ml} / \mathrm{min}$ using a pump (403U/VM2; Watson-Marlow), with saline running through an inline heater to maintain the temperature at $34^{\circ} \mathrm{C}$ ( $\mathrm{SH}-27 \mathrm{~B}$ with TC-324B controller; Warner Instruments).

Pipettes were pulled from borosilicate glass (OD: $1.5 \mathrm{~mm}$, ID: 0.86 $\mathrm{mm}$; Sutter Instruments) to a resistance of 1-2 M $\Omega$ and were filled with internal solution containing the following (in $\mathrm{mm}$ ): for voltage clamp, 35 CsF, $100 \mathrm{CsCl}, 10 \mathrm{EGTA}, 10 \mathrm{HEPES}$, and 1 QX-314; or for current clamp, $130 \mathrm{KMeSO}_{3}, 10 \mathrm{NaCl}, 2 \mathrm{MgCl}_{2}, 0.16 \mathrm{CaCl}_{2}, 0.5$ EGTA, 10 HEPES, 2 $\mathrm{Na}_{2} \mathrm{ATP}, 0.4 \mathrm{NaGTP}$, and 14 Tris-CrPhos (pH 7.3, $305 \mathrm{mOsm}$ ).

For voltage-clamp experiments in Figures 2-5, BCs were held at -70 $\mathrm{mV}$, with access resistance 5-15 $\mathrm{M} \Omega$ compensated to $70 \%$. Cells were identified by EPSCs having rapid decay kinetics $(\tau<0.2 \mathrm{~ms})$ and halfwidth $\leq 0.5 \mathrm{~ms}$ (Chanda and Xu-Friedman, 2010). For current-clamp experiments in Figure 7, BCs were maintained at $-60 \mathrm{mV}$ and were identified by their 1 to 2 undershooting spikes in response to depolarizing current pulses (Wu and Oertel, 1984). Single fibers were stimulated using a glass microelectrode placed $30-50 \mu \mathrm{m}$ away from the soma with currents of 5-22 $\mu \mathrm{A}$ through a stimulus isolator (WPI, A360). Single or paired pulses were applied every $10 \mathrm{~s}$. Train stimuli were applied every 30 s. For the integration method, trains of 45 ESPCs were evoked, in the presence of $1 \mathrm{~mm}$ kynurenate to prevent postsynaptic receptor desensitization and saturation.

Immunohistochemistry. Mice were anesthetized with $200 \mathrm{mg} / \mathrm{kg}$ ketamine and $10 \mathrm{mg} / \mathrm{kg}$ xylazine, then perfused transcardially with $0.9 \%$ saline followed by $4 \%$ buffered PFA. Brains were removed and postfixed (room temperature, $2 \mathrm{~h}$ ) before cryoprotecting in $20 \%$ sucrose $\left(4^{\circ} \mathrm{C}\right.$, overnight). Sagittal sections were cut frozen at $50 \mu \mathrm{m}$ thickness on a sliding microtome (American Optical). Slices were treated with $0.5 \%$ Triton X-100 in $0.2 \mathrm{M}$ PBS for $10 \mathrm{~min}$. The slices were then blocked in $1 \%$ normal goat serum for $1 \mathrm{~h}$ at room temperature, washed three times in $0.2 \mathrm{M}$ PBS solution, and incubated overnight at $4^{\circ} \mathrm{C}$ in primary antibody solution containing the following: anti-VGLUT-1 (Invitrogen) at 1:500, and $0.2 \mathrm{M}$ PBS with $0.5 \%$ Triton X-100. The sections were then washed three times in $0.2 \mathrm{M}$ PBS with $0.5 \%$ Triton X-10 and incubated for $2 \mathrm{~h}$ with 1:200 FITC-conjugated goat anti-rabbit antibody in $0.2 \mathrm{M}$ PBS, $0.5 \%$ Triton X-100. The sections were then mounted on glass slides using Fluoromount G with DAPI (Southern Biotechnology). 
A

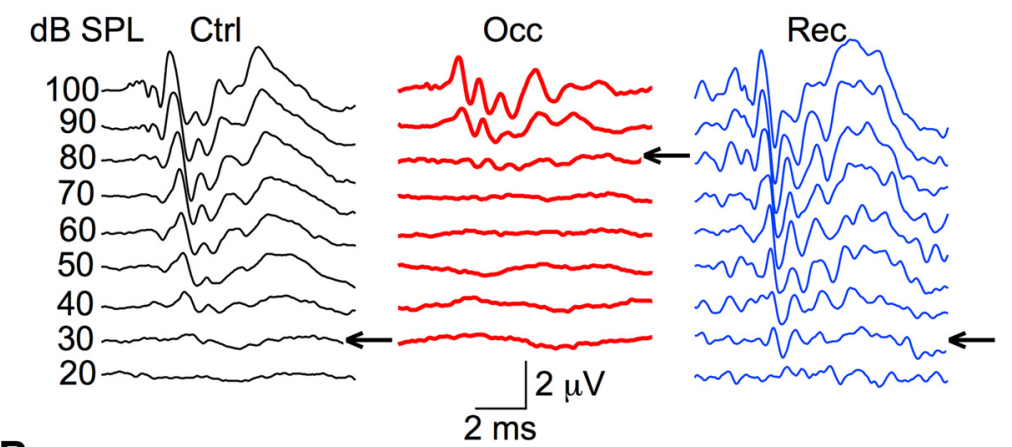

B

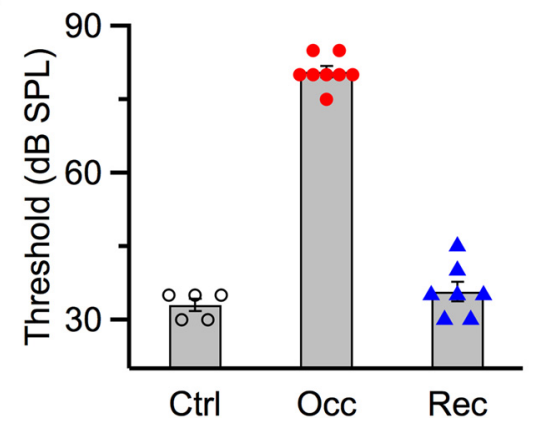

Figure 1. Assessing hearing thresholds using ABRs before, during occlusion, and following recovery from occlusion. $A$, Representative traces from a P20 control mouse (left), a P19 occluded mouse (middle), and a P27 recovered mouse (right). Traces were evoked by click stimuli and were averages of 1024 trails. Thresholds are indicated by arrows. $\boldsymbol{B}$, Average ABR thresholds for control (5 ears), bilateral occlusion (8 ears), and recovery (7 ears). After occlusion, thresholds were significantly elevated by $48.0 \pm 1.6 \mathrm{~dB}$ $\operatorname{SPL}(p<0.001)$. After recovery, thresholds were not significantly different compared with control $(p>0.1)$.

Following occlusion, threshold was significantly elevated to $80.0 \pm 1.1 \mathrm{~dB}$ SPL ( 8 ears; $p<0.01$ ), and after removing occlusion, threshold was back to $36.0 \pm 2.0 \mathrm{~dB}$ SPL (7 ears; $p=0.28$ ) (Fig. $1 B$ ). This indicates that the methods to create occluded and recovered ears are valid and reliable.

\section{Occlusion affects endbulb function}

We studied how bilateral occlusion affects synaptic function by characterizing endbulbs in terms of release probability $\left(P_{\mathrm{r}}\right)$, quantal size $(Q)$, and number of release sites $(N)$. We first assessed $P_{\mathrm{r}}$ by quantifying the level of synaptic depression. We recorded pairs of EPSCs at different intervals $(\Delta t)$ from BCs in whole-cell voltage clamp, and calculated the pairedpulse ratio (PPR), which is the amplitude of the second EPSC normalized to the first $\left(\mathrm{PPR}=\mathrm{EPSC}_{2} / \mathrm{EPSC}_{1}\right)$. Endbulbs normally show depression (Fig. 2A, left) and small PPR (Fig. 2B, open circles) at all intervals, indicating they have high $P_{\mathrm{r}}$. Endbulbs from occluded mice showed even stronger depression (Fig. 2A, right) and smaller PPR (Fig. 2B, closed circles), indicating they have higher $P_{\mathrm{r}}$. We found similar results across multiple recordings. Average PPR for $\Delta t=3 \mathrm{~ms}$ was $0.50 \pm$ 0.03 (13 cells) in control mice versus

Confocal images were acquired using an Olympus confocal microscope. All images were taken with similar settings for both control and occlusion conditions. BCs were identified by clear labeling of VGLUT1positive puncta around the soma, and 3 or 4 well-separated BCs from each mouse were chosen for analysis. BCs without recognizable puncta would not be included in this analysis. All of the quantification was performed blind to rearing conditions by randomly naming image files. To quantify the average number and area of puncta, the optical section at the midline of each cell was selected and Yen's threshold algorithm (Yen et al., 1995) plug-in in ImageJ was applied to identify puncta. The automated analyze particles command in ImageJ was used to scan the threshold image and find the edges of puncta. Outlines of the particles were verified against the original image to confirm the detection of puncta. The puncta not belonging to the cell were excluded, and particles that were part of one puncta were merged.

Data analysis. Average results are reported throughout as mean \pm SEM. All statistical tests are unpaired Student's $t$ tests, except where otherwise noted.

\section{Results}

\section{Verifying ear occlusion and removal}

To generate bilateral CHL, we occluded ears reversibly, using either an earplug or ligature of the ear canal. We validated successful ear occlusion and occlusion removal by measuring hearing threshold with ABRs. In the example of Figure $1 A$ (left), a control mouse at P20 had a hearing threshold of $30 \mathrm{~dB}$ SPL. For a mouse with ear canal ligated at P14, the threshold was $80 \mathrm{~dB}$ SPL measured at P19 (Fig. 1A, middle), reflecting a decrease in sensitivity of $\sim 50 \mathrm{~dB}$ SPL. In the example shown in Figure $1 A$ (right), the mouse was ligated at P21, then unligated at P24, and by P27, the threshold recovered to $30 \mathrm{~dB}$ SPL, indicating that these shifts were reversible. We found similar results in all ears tested. The average threshold of control mice was $33.0 \pm 1.2 \mathrm{~dB}$ SPL ( 5 ears).
$0.31 \pm 0.02$ (22 cells) in occluded mice, which is significantly lower $(p<0.01)$. PPRs at other intervals were also significantly lower following occlusion (Fig. $2 C ; p<0.05$ ), indicating that endbulbs had higher $P_{\mathrm{r}}$ after occlusion.

In theory, if all other synaptic properties remain equal, an increase in $P_{\mathrm{r}}$ should lead to larger initial EPSCs. However, we found that the amplitudes of first EPSC $\left(\mathrm{EPSC}_{1}\right)$ in control versus occluded mice were not significantly different (Fig. 2D; control: 28 cells; occlusion: 45 cells; $p=0.34$, Kolmogorov-Smirnov test). This indicates that other changes must be taking place to offset the increase in $P_{\mathrm{r}}$.

In addition, it is important to understand how quickly $P_{\mathrm{r}}$ changes following occlusion. To address this, we occluded ears at $\mathrm{P} 14$ (the onset of hearing) and assessed PPR for $\Delta t=3 \mathrm{~ms}$ starting from P15 (Fig. 2E). We detected a significant decrease after 1 week of occlusion, starting from P21 (Fig. 2F).

\section{Quantal size remains unchanged after occlusion}

An important form of activity-dependent homeostasis is synaptic scaling, in which decreased activity leads to an increase in $Q$ (O'Brien et al., 1998; Turrigiano et al., 1998; Turrigiano and Nelson, 2004; Keck et al., 2013). We tested for synaptic scaling in endbulbs by recording spontaneous mEPSCs in voltage clamp from occluded and control mice (Fig. 3A). The average frequency and amplitude were calculated by recording 70-250 mEPSCs from each cell. Spontaneous mEPSC frequency in occluded mice was similar to that in control mice (control: 12 cells; occlusion: 13 cells; $p=0.60$, Kolmogorov-Smirnov test; Fig. $3 B$ ). Spontaneous average mEPSC amplitudes in occluded mice were also similar to those in control mice (control: 12 cells; occlusion: 13 cells; $p=$ 0.56, Kolmogorov-Smirnov test) (Fig. 3C). The mEPSC ampli- 
tudes were also analyzed by taking 100 mEPSCs from cells with sufficient number of mESPCs and merging into two overall distributions for control versus occluded conditions. This approach also showed no difference between control and occluded mESPC amplitudes (control: 8 cells; occlusion: 6 cells; $p=0.12$, Kolmogorov-Smirnov test; Fig. 3D). Thus, the mEPSCs were not affected by occlusion, suggesting that synaptic scaling does not occur under our conditions. Instead, a separate mechanism appears to be involved in the changes we observed in response to reduced activity.

\section{Quantification of $P_{\mathrm{r}}, N$, and $Q$}

Our direct measurements of PPRs and mEPSCs suggested that $P_{\mathrm{r}}$ increased and $Q$ did not change after CHL. To verify these changes and also to quantify $N$, we used mean-variance analysis and the integration method. Mean-variance analysis is based on considering neurotransmitter release as a binomial random process, so the mean $(\mu)$ and variance $\left(\sigma^{2}\right)$ of the EPSC amplitude are related according to $\sigma^{2}=Q \mu-\left(\mu^{2} / N\right)$, when $P_{\mathrm{r}}$ is varied by changing external calcium concentrations $\left(\mathrm{Ca}_{\mathrm{e}}\right)$ (Silver, 2003; Foster and Regehr, 2004). We measured EPSC amplitude in different $\mathrm{Ca}_{\mathrm{e}}(1,1.5$, and $3 \mathrm{~mm})$ in BCs from control (Fig. 4A) and occluded mice (Fig. 4C). Mean-variance plots were fitted with the equation above to estimate $N$ and $Q$, and then $P_{\mathrm{r}}$ at normal $\mathrm{Ca}_{\mathrm{e}}(1.5 \mathrm{~mm})$ could be calculated by $P_{\mathrm{r}}=\mathrm{EPSC} / \mathrm{QN}$ (Fig. $4 B, D$ ). Figure 4 shows examples of a control endbulb (Fig. 4A,B) and an occluded endbulb (Fig. 4C,D). We made similar measurements in a number of BCs, which indicated that after occlusion $N$ decreased significantly (Fig. $4 E$; control: $98 \pm 8,9$ cells; occlusion: $70 \pm 9,16$ cells; $p=0.03$ ), and $P_{\mathrm{r}}$ increased significantly (Fig. $4 F$; control: $0.43 \pm 0.04,9$ cells; occlusion: $0.55 \pm 0.03,16$ cells; $p=0.03)$. No significant difference was detected between control and occluded mice in $Q$ (Fig. 4G; control: $124 \pm 12,9$ cells; occlusion: $151 \pm 15,16$ cells; $p=0.17$ ).

In addition to the mean-variance analysis, we also used an independent method based on long trains (Schneggenburger et al., 1999; Thanawala and Regehr, 2013, 2016). EPSCs (100 Hz, 45 pulses) were evoked from control (Fig. 4H) and occluded BCs (Fig. $4 \mathrm{~J}$ ), in the presence of $1 \mathrm{~mm}$ kynurenate to prevent postsynaptic receptor desensitization and saturation. The EPSCs were integrated, and the rate of vesicle recovery was estimated by a straight-line fit to the last 20 pulses of the cumulative EPSC (Fig. $4 I, K)$. The $y$-intercept was proportional to $N$, and dividing the first EPSC by $N$ yields $P_{\mathrm{r}}$. We did similar experiments in a number of control and occluded BCs. The results indicated that $N$ significantly decreased (Fig. $4 L$; control: $5.2 \pm 0.6 \mathrm{nA}, 11$ cells; occlusion: $3.7 \pm 0.4 \mathrm{nA}, 10$ cells; $p=0.04)$ and $P_{\mathrm{r}}$ significantly increased (Fig. $4 M$; control: $0.38 \pm 0.03,11$ cells; occlusion: $0.47 \pm 0.03,10$ cells; $p=0.04$ ) after occlusion. Thus, both meth-
B
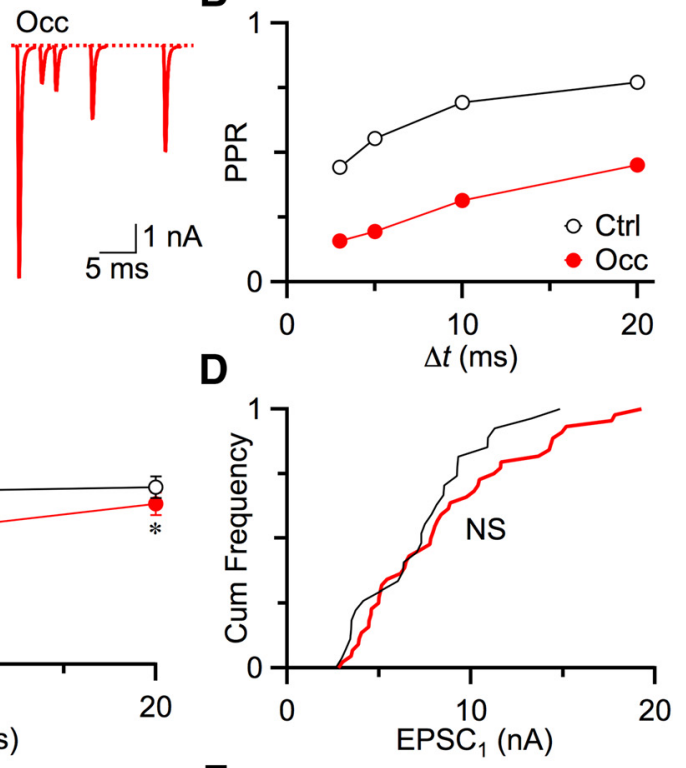

$\mathbf{F}$

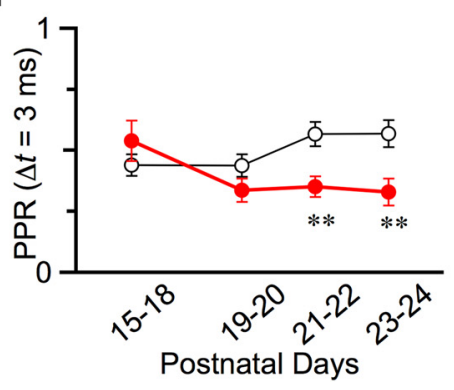

Figure 2. $\quad P_{\mathrm{r}}$ at endbulbs increased after occlusion. $\boldsymbol{A}$, Representative EPSC traces recorded from a BC in a P20 control mouse (left) and in a P23 occluded mouse (right). Single auditory nerve fibers were stimulated in pairs with interpulse intervals from 3 to $20 \mathrm{~ms}$. istributions. There was no significant difference between control ( 28 cells) and occlusion (45 cells) (NS, p>0.5, Kolmogorov$F$, PPR as a function of age, averaged over $\geq 2$ days from control and occluded mice. PPRs after occlusion were significantly smaller starting at P21 (P15-P18: $p=0.3 ; \mathrm{P} 19-\mathrm{P} 20: p=0.15 ; \mathrm{P} 21-\mathrm{P} 22: p=0.004 ; \mathrm{P} 23-\mathrm{P} 24: p=0.01)$.

ods showed that occlusion led to increased $P_{\mathrm{r}}$, and mean-variance analysis also showed no change in $Q$, consistent with our measurements of PPR and mEPSCs. In addition, both methods indicated $N$ decreased after ear occlusion, which may account for the

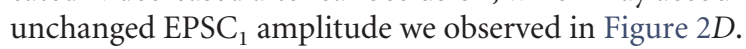

\section{Recovery of $P_{\mathrm{r}}$ and $N$}

We also tested whether the changes in $P_{\mathrm{r}}$ and $N$ we observed in Figure 4 recover after returning to normal sound conditions. We found that, for ears ligated at very early ages (P14), it was difficult to surgically reopen the ear canal. Therefore, for this set of experiments, we ligated the ear canal at P21 and unligated at P24 (Fig. $5 A)$. We first used the integration method to confirm that $3 \mathrm{~d}$ of ligation was enough to affect $N$ and $P_{\mathrm{r}}$ (Fig. $5 A$, "Occ"). We found that, by P24, $N$ decreased compared with age-matched controls (Fig. $5 A$, “Ctrl early $_{\text {") }}$ (control: $5.5 \pm 0.7 \mathrm{nA}, 10$ cells; occlusion: $3.6 \pm 0.6 \mathrm{nA}, 11$ cells; $p=0.04 ;$ Fig. $5 B$ ) and $P_{\mathrm{r}}$ increased (control: $0.39 \pm 0.03,10$ cells; occlusion: $0.54 \pm 0.04,11$ cells; $p=0.009$; Fig. $5 C$ ). Then in another group of mice, we unligated at P24 and assessed recovery of $N$ and $P_{\mathrm{r}}$ after 1 week (Fig. $5 A$, "Rec"). In these animals, $N$ returned to near age-matched controls (Fig. $5 A$, 
A

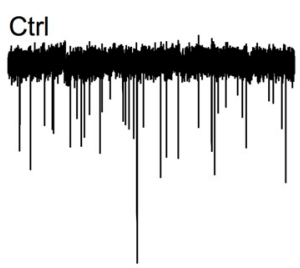

B
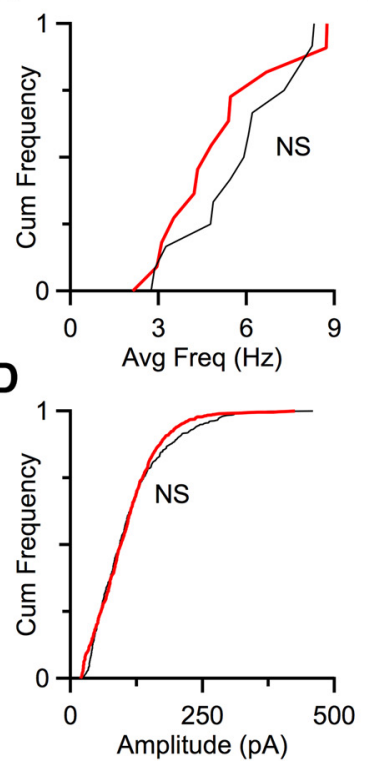

Figure 3. Q remained the same after occlusion. $\boldsymbol{A}$, Representative spontaneous mEPSCs from a control mouse (left) and an occluded mouse (right). Cumulative frequency plots of average $\mathrm{mEPSC}$ frequency $(\boldsymbol{B})$ and amplitude ( $\boldsymbol{C}$ ) from mice under control (13 cells) and occlusion (12 cells) condition. Occlusion had no significant effect on mEPSC amplitude ( $p>0.1$, Kolmogorov-Smirnov test) or frequency ( $p>0.5$, Kolmogorov-Smirnov test) of mEPSC. D, Cumulative frequency plots of 100 events total per cell under control (6 cells) and occlusion (8 cells) conditions. No significant difference was observed between control and occluded BCs ( $p>0.1$, Kolmogorov-Smirnov test).

“Ctrl $l_{\text {late }}$ ") (control: $5.2 \pm 0.9 \mathrm{nA}, 13$ cells; recovery: $5.0 \pm 0.8 \mathrm{nA}$, 15 cells; $p=0.83$; Fig. $5 B$ ) and $P_{\mathrm{r}}$ decreased toward control levels (control: $0.37 \pm 0.05,13$ cells; recovery: $0.45 \pm 0.02,15$ cells; $p=$ 0.13 ; Fig. $5 C$ ). Thus, $P_{\mathrm{r}}$ does show recovery after hearing is restored, but recovery does not appear to be complete after 1 week, while $N$ seems to fully recover.

We were concerned that the mathematical analyses associated with the integration method could introduce additional variability into the estimate of $P_{\mathrm{r}}$. Therefore, we also assessed recovery using the PPR at $\Delta t=3 \mathrm{~ms}$, which is very sensitive to changes in $P_{\mathrm{r}}$. PPR decreased significantly from $0.55 \pm 0.04\left(\mathrm{Ctrl}_{\text {early }}, 13\right.$ cells) to $0.41 \pm 0.03$ (Occ, 10 cells) after $3 \mathrm{~d}$ of occlusion $(p=$ $0.01)$, reflecting an increase in $P_{\mathrm{r}}$. In another set of mice, we occluded ears at P21 and unoccluded them at P24, then measured PPR after P30. PPR in these animals was $0.55 \pm 0.04$ (Rec, 9 cells), which was significantly greater than the occluded cells $(p=0.03)$, but not significantly different from PPR measured in mice after P30 that were never occluded $\left(\mathrm{Ctrl}_{\text {late }}, \mathrm{PPR}=0.53 \pm 0.04,10\right.$ cells, $p=0.85$ ). Thus, PPR appeared to recover completely after occlusion was removed.

\section{Endbulb structural changes after occlusion}

The physiological experiments using mean-variance analysis and the integration method indicated that ear occlusion caused a de- crease in the number of release sites or vesicles (Fig. $4 E, L$ ). Deafening in mice and cats has been linked to changes in endbulb structure (Limb and Ryugo, 2000; O'Neil et al., 2011; Connelly et al., 2016), so we examined whether ear occlusion had similar effects by using VGLUT1 immunohistochemistry, which labels glutamatergic vesicles around multiple release sites (Lauer et al., 2013; Ngodup et al., 2015). Figure 6A shows examples of VGLUT1-labeled endbulbs from control (left) and occluded mice (right), which contained strong punctate labeling surrounding the $\mathrm{BC}$ somata. We quantified the number of puncta around the cell body in single optical sections in the middle of the cell. We used an automated detection and measurement algorithm (Yen et al., 1995) in Image J and did the analysis blind to treatment conditions. Figure $6 B$ shows outlines of puncta around the BC cell body from example control (Fig. 6B, left) and occluded (Fig. $6 B$, right) mice. We did the same analysis on multiple cells from control and occluded mice. There was no significant change in the number of puncta after occlusion (Fig. $6 C$; control: $12.3 \pm 1.1,10$ cells; occlusion: $12.8 \pm 0.9,10$ cells; $p=0.72$ ). By contrast, the average area of puncta shrank after occlusion (Fig. $6 D$; control: $2.6 \pm 0.3 \mu \mathrm{m}^{2}, 10$ cells; occlusion: $1.6 \pm 0.2 \mu \mathrm{m}^{2}, 14$ cells; $p=0.01)$. This indicates that endbulb structure changes following occlusion and is consistent with the decrease in the number of release sites found using mean-variance analysis and the integration method.

\section{Decreasing excitability of BCs after occlusion}

In addition to synaptic properties, acoustic environment and activity can also affect postsynaptic intrinsic properties, such as by modulating channels (Song et al., 2005). We characterized the intrinsic electrical properties in current-clamp recordings by injecting current pulses into BCs from control and occluded mice. As in control (Oertel, 1983), BCs from occluded mice fired one undershooting action potential in response to depolarizing current injection (Fig. 7A). There was no significant difference in firing thresholds between BCs of control and occluded mice (Fig. $7 B$; control: $-46.2 \pm 1.2 \mathrm{mV}, 8$ cells; occlusion: $-46.6 \pm 0.7 \mathrm{mV}$, 24 cells; $p=0.77)$. We also used these data to characterize the input resistance $\left(R_{\text {in }}\right)$. Figure $7 C$ shows the average membrane voltage as a function of current injection for control and occluded BCs. The shallower slope in Figure $7 C$ indicated that $R_{\text {in }}$ decreased after occlusion. We calculated $R_{\text {in }}$ around resting membrane potential $(-60 \mathrm{mV})$, which was significantly higher in control compared with occluded mice (Fig. $7 D$; control: $66.3 \pm$ 9.2 M $\Omega, 8$ cells; occlusion: $38.8 \pm 6.7 \mathrm{M} \Omega, 24$ cells; $p=0.017$ ). This may indicate that the expression level of potassium channels at postsynaptic BCs increased following occlusion (BarnesDavies et al., 2004; Lu et al., 2004).

The deeper depression and lower $R_{\text {in }}$ would both be expected to influence synaptically evoked spiking in BCs. We tested this by stimulating a single auditory nerve fiber 20 times at 100 or 200 $\mathrm{Hz}$. After occlusion, the BCs fired fewer action potentials at both 100 (Fig. 7E) and $200 \mathrm{~Hz}$ (Fig. 7F). We quantified firing probability during the second half of the train (pulses 11-20) when EPSPs are near steady state. Firing probability was significantly lower in occluded mice than in control mice at both $100 \mathrm{~Hz}$ (Fig. $7 G$; control: $0.84 \pm 0.10,5$ cells; occlusion: $0.39 \pm 0.12,9$ cells; $p=0.013$ ) and $200 \mathrm{~Hz}$ (Fig. $7 \mathrm{H}$; control: $0.50 \pm 0.10,5$ cells; occlusion: $0.12 \pm 0.05,9$ cells; $p=0.014$ ). Therefore, it appears that the excitability of BCs decreased following occlusion. 
A Ctrl
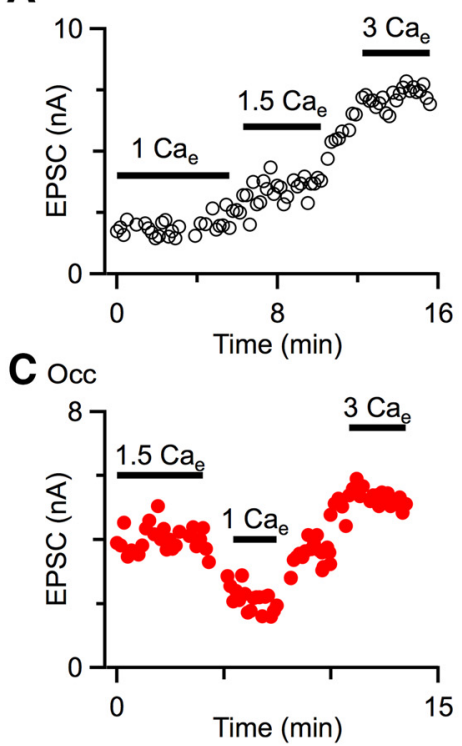

E

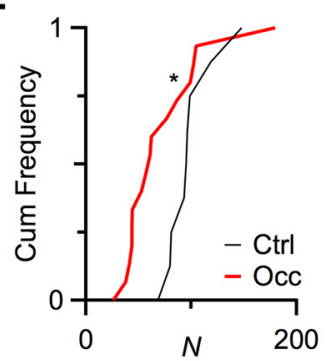

$\mathbf{F}$
B
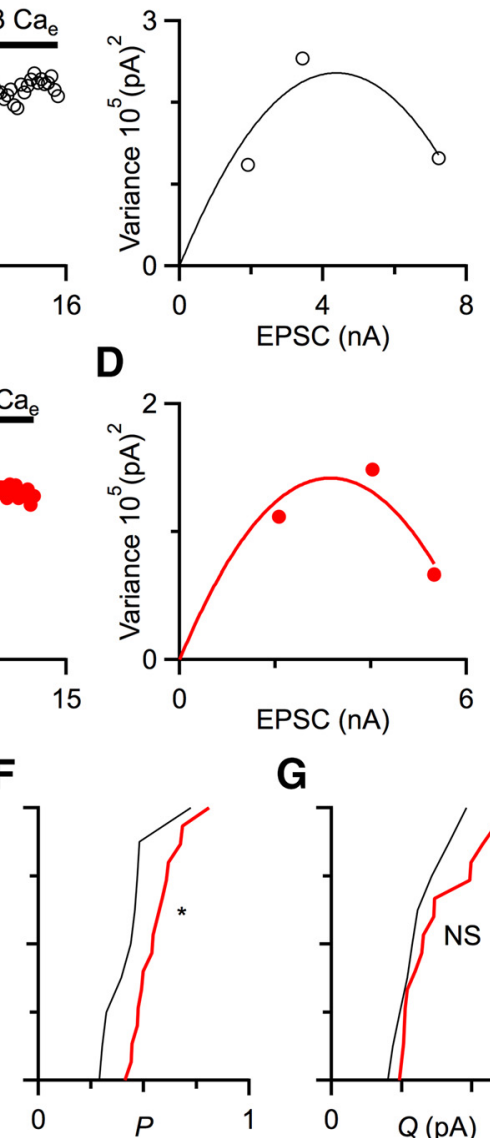

G

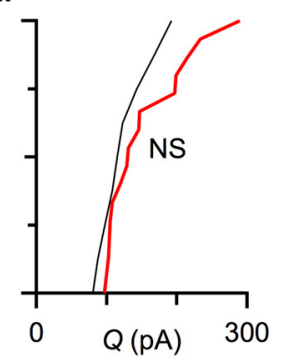

H Ctrl

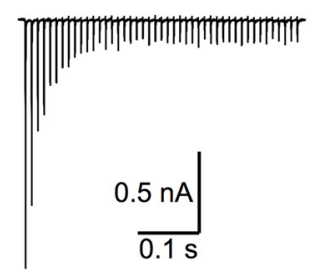

$\mathbf{J}$ Occ

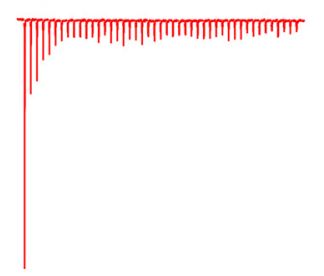

I
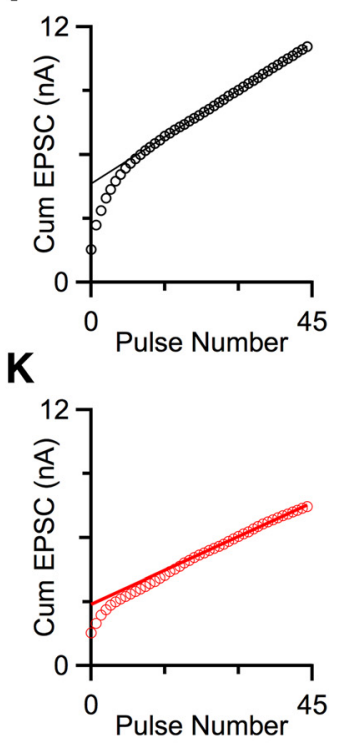

$\mathbf{L}$

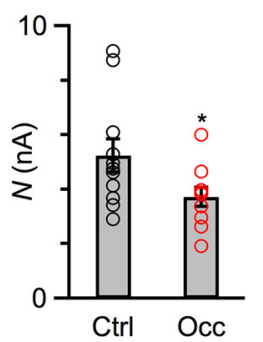

M

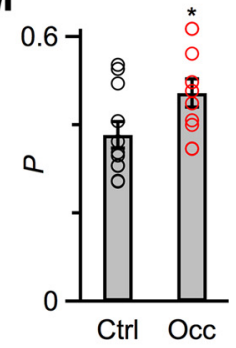

Figure 4. Quantification of $P_{r}, N$, and $Q . A, C$, Example experiments showing effects of different $C_{\mathrm{e}}$ on EPSC amplitude over the course of the experiment from a control mouse (P22, $\boldsymbol{A}$ ) and an occluded mouse $\left(P 23, \boldsymbol{C}\right.$ ). Lines above the points indicate the data that are used for analysis. $\boldsymbol{B}, \boldsymbol{D}$, Markers indicate variance versus EPSC amplitude for each $\boldsymbol{C a}_{\mathrm{e}}$ concentration from experiments in $\boldsymbol{A}$ and $\boldsymbol{C}$. Lines are fits to the equation $\sigma^{2}=Q \mu-\left(\mu^{2} / N\right)$, with $N=81$ and $Q=108$ in $\boldsymbol{B}$, and $N=70$ and $Q=90$ in $\boldsymbol{D}$. From these, $P_{\mathrm{r}}$ at 1.5 Ca is calculated to be 0.39 in $\boldsymbol{B}$, and 0.64 in $\boldsymbol{D}$. $\boldsymbol{E}-\boldsymbol{G}$, Cumulative frequency plot of $N(\boldsymbol{E}), P_{\mathrm{r}}(\boldsymbol{F})$, and $Q(\boldsymbol{G})$ from control mice ( 9 cells, black) and occluded mice ( 16 cells, red). After occlusion, $N$ significantly decreased and $P_{\mathrm{r}}$ significantly increased $(p<$ 0.05). Q showed no significant changes $(p>0.1)$. $\boldsymbol{H}, \boldsymbol{J}$, Representative long trains recordings in the presence of 1 mm kynurenate from a control mouse $(\boldsymbol{H})$ and an occluded mouse $(\boldsymbol{J})$ in response to stimulation of a single AN fiber ( $100 \mathrm{~Hz}, 45$ pulses). $\boldsymbol{I}, \boldsymbol{K}$, EPSC amplitude is integrated, and a fit is extrapolated back from the last 20 cumulative EPSCs to the $y$-axis to estimate $N$ (straight line). $P_{r}$ is calculated by dividing the first EPSC by $N$. $\boldsymbol{L}, \boldsymbol{M}$, Quantification of $N(\boldsymbol{L})$ and $P_{\mathrm{r}}(\boldsymbol{M})$ using the integration method from control mice (11 cells) and occluded mice (10 cells). 0 ccluded endbulbs showed significantly smaller $N\left({ }^{*} p<0.05\right)$ and higher $P_{r}\left({ }^{*} p<0.05\right)$.

\section{Discussion}

We have shown that CHL changes fundamental properties of endbulbs and BCs in the AVCN. $P_{\mathrm{r}}$ increased after occlusion and reverted when normal conditions were restored. Moreover, $N$ decreased, appearing to compensate for increased $P_{\mathrm{r}}$ to maintain a constant $\mathrm{EPSC}_{1}$. Q remained constant in response to occlusion. These results indicate that endbulbs respond homeostatically to $\mathrm{CHL}$, but not through synaptic scaling. These as well as intrinsic changes in $R_{\text {in }}$ led to decreased postsynaptic firing in BCs.

These cellular and synaptic changes appear to optimize cellular properties in response to reduced auditory activity. High $P_{\mathrm{r}}$ causes synaptic depletion, but when the activity is low, there is increased opportunity for recovery, so the consequences of high $P_{\mathrm{r}}$ are minimal. By contrast, maintaining a large endbulb with many unused vesicles may be inefficient. Therefore, dropping $N$ and raising $P_{\mathrm{r}}$ could make endbulbs more efficient when auditory activity is low.

\section{Consequences of CHL}

These synaptic and cellular effects may have relevance for the long-lasting effects of OM, which is common among young children (Gates, 1996; Zhou et al., 2008). OM can have long-term behavioral consequences, including shifts in sensitivity to interaural level and timing differences and also in FM detection thresholds (Thornton et al., 2012; Buran et al., 2014; Caras and Sanes, 2015). However, the cellular basis is not well understood. Our studies showed that $P_{\mathrm{r}}$ increased at endbulbs during CHL, which may initially yield little change in spike fidelity at endbulbs when activity is reduced. However, when normal hearing is restored and activity increases, synaptic depletion could become significant, which would reduce spike fidelity and possibly impair perception.

Importantly, we observed changes at the start of the auditory pathway, and similar mechanisms likely exist throughout the pathway. These changes may have negative consequences, particularly if CHL resolves and the synapses do not recover accordingly. Early CHL can engender susceptibility to audiogenic seizures (Henry, 1967; Sun et al., 2011). In auditory cortex, pyramidal neurons and inhibitory synapses onto them were permanently altered when CHL occurred before P18 (Mowery et al., 2015), which may underlie changes in auditory behavior following CHL (Popescu and Polley, 2010; Polley et al., 2013; Caras and Sanes, 2015). We found that $P_{\mathrm{r}}$ at endbulbs largely recovered after normal sound conditions were restored (Fig. 5), indicating that 
A

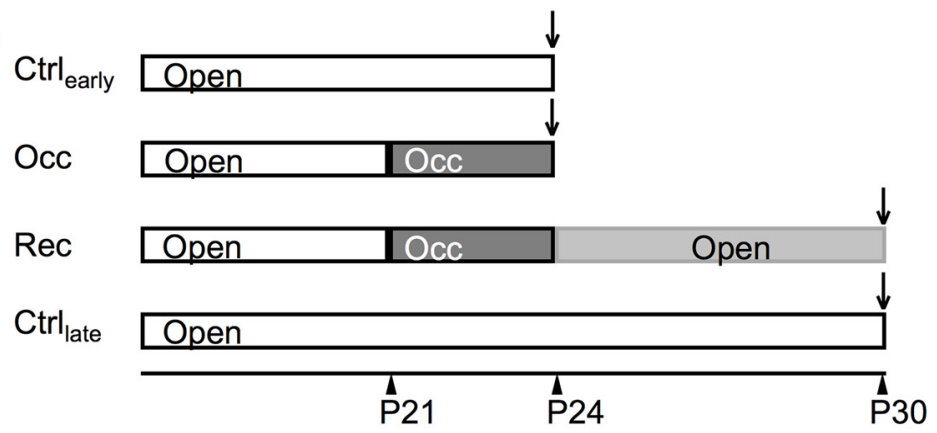

\section{B}

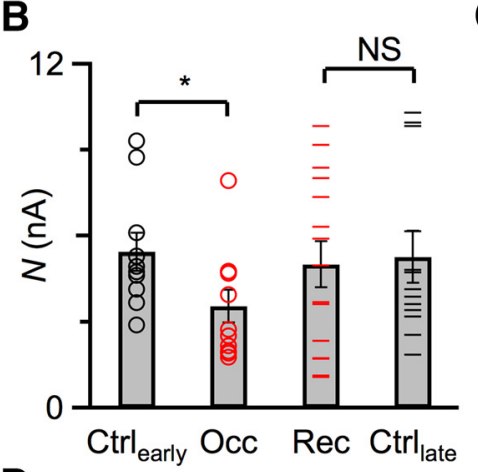

D

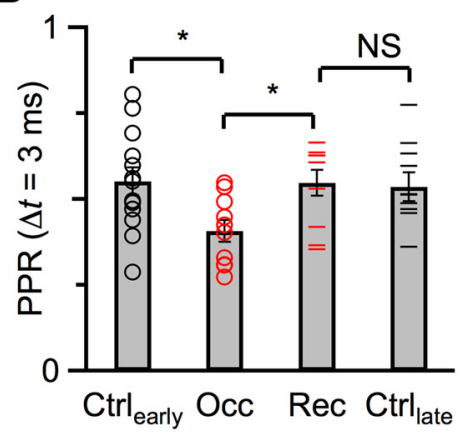

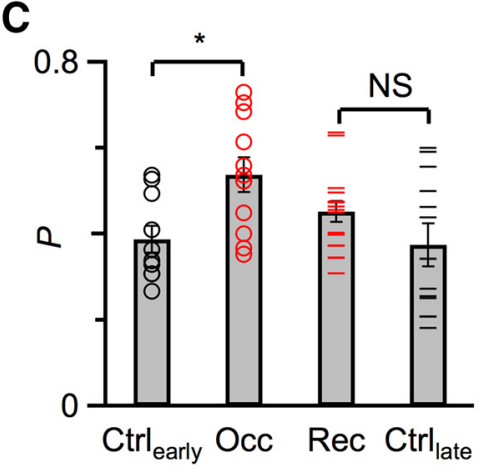

Figure 5. Recovery of $P_{\mathrm{r}}$ and $N$ after returning to normal sound conditions. $A$, Experimental timeline for the 4 experimental groups shown in $\boldsymbol{B}$ and $\boldsymbol{C}$. One group of mice ( $\left(\mathrm{Crl} \mathrm{e}_{\text {early }}\right)$ were raised under normal sound conditions, and recordings were performed around P24. The second group $(0 \mathrm{cc})$ were occluded at P21 until recording at P24. The third group (Rec) were ligated at P21, unligated at $\mathrm{P} 24$, and recorded after $\mathrm{P} 30$. The fourth group $\left(\mathrm{Ctrl}_{\text {late }}\right)$ were raised under normal sound conditions and recorded after P30. Quantification of $N(\boldsymbol{B})$ and $P_{\mathrm{r}}(\boldsymbol{C})$ using the integration method from $\left(\mathrm{trl} \mathrm{e}_{\text {early }}\right.$ group (10 cells), Occ group (11 cells), $\mathrm{Ctrl}_{\text {late }}$ group (13 cells), and Rec group (15 cells), similar to Figure 4. D, Measurement of PPR at $\Delta t=3 \mathrm{~ms}$ for treatment groups in $\boldsymbol{A}$. These measurements were performed in the absence of kynurenate and were therefore done on separate cells from those shown in $\boldsymbol{B}$ and C. Error bars indicate mean \pm SEM. Markers indicate individual $B C s .{ }^{*} p<0.05$.

endbulbs adapt to acoustic conditions even after early development. Such flexibility may be needed because the auditory periphery continues to change throughout life (Schmiedt et al., 1996; Skoe et al., 2015). Therefore, it may be useful to study the cellular mechanisms underlying CHL-dependent changes in endbulbs, to learn how to reverse nonadaptive changes at other stages of the auditory pathway that impede normal processing.

It will also be important to establish how other synapses in the auditory pathway are affected by CHL. This has been considered at the calyx of Held in the medial nucleus of the trapezoid body using unilateral CHL. Calyces carrying information from the occluded ear showed no change in $P_{\mathrm{r}}$, but calyces from the nonoccluded ear showed reduced $P_{\mathrm{r}}$ (Grande et al., 2014). Also, unilateral CHL led to changes in AMPAR expression (Wang et al., 2011; Clarkson et al., 2016). Such receptor changes might affect mEPSCs, but we observed no changes in mEPSC amplitude or decay with bilateral occlusion. It is difficult to tell whether these

effects reflect a fundamentally different underlying phenomenon or whether changes in activity are more complicated following unilateral occlusion, compared with the bilateral occlusion.

We found that both juvenile and mature synapses in mice were sensitive to CHL, suggesting that human endbulbs could be too, although there are significant differences between the auditory systems of mice and humans. To understand this better, it will be important to investigate further the time course and age dependence of recovery, as well as the perceptual consequences.

\section{Other models of hearing loss}

Our results may relate to additional models of reduced activity. For example, mutations of bassoon, a presynaptic scaffolding protein, and otoferlin, the putative calcium sensor at hair cell synapses, both reduced afferent activity and increased $P_{\mathrm{r}}$ at endbulbs (Mendoza Schulz et al., 2014; Wright et al., 2014), consistent with our findings. Bassoon and otoferlin mutations also led to larger $Q$, likely reflecting homeostatic synaptic scaling (Turrigiano et al., 1998; Keck et al., 2013), which we did not observe after occlusion (Figs. 3, 4). This may be because ligation preserves much of ear function, including spontaneous activity and receptivity to self-generated sounds. $\mathrm{Mu}$ tations of bassoon and otoferlin may have had a more severe impact on auditory activity, which could recruit additional homeostatic mechanisms, such as synaptic scaling. This would imply that there are multiple signaling pathways with different thresholds for activity that induce changes in $P_{\mathrm{r}}$ and $N$ vs $Q$.

By contrast, early-onset hearing loss in DBA mice led to smaller $P_{\mathrm{r}}$ and $Q$ (Wang and Manis, 2005), which is not consistent with the effects we observed after occlusion. To reconcile these findings, it will be important to understand how cochlear degeneration affects acoustically driven and spontaneous activity, as well as the activity-dependent signaling pathways that regulate endbulb properties.

Furthermore, many studies have examined how deafening affects the avian auditory system using such manipulations as middle and inner ear damage (Tucci and Rubel, 1985; Tucci et al., 1987; Harris and Rubel, 2006; Kuba et al., 2010, 2014). Such manipulations have dramatic effects on cell structure and excitability in the homologous nucleus magnocellularis. However, the consequences for chick endbulb physiology are not well known. It will be interesting to examine whether similar manipulations have similar effects in mammalian and avian systems.

\section{Quantification of $N, P_{\mathrm{r}}$, and $Q$}

We assessed synaptic parameters using mean-variance analysis and the integration method. It is important to interpret the values 
A
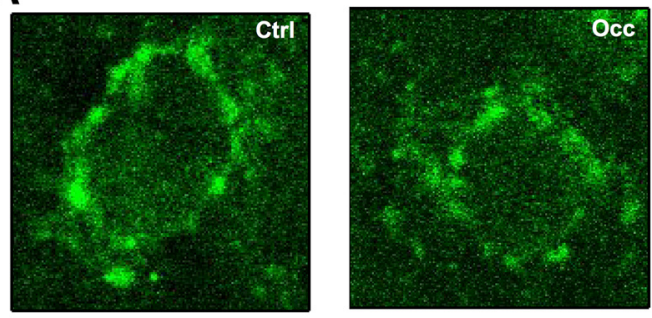

B

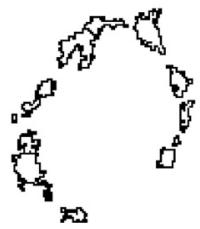

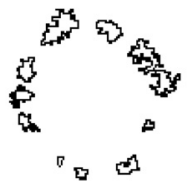

$10 \mu \mathrm{m}$

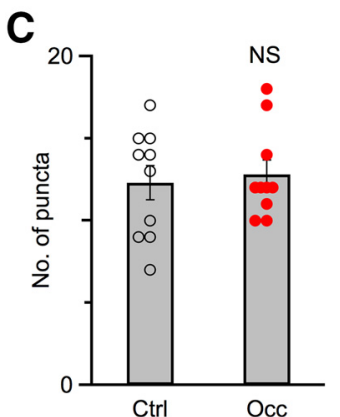

D

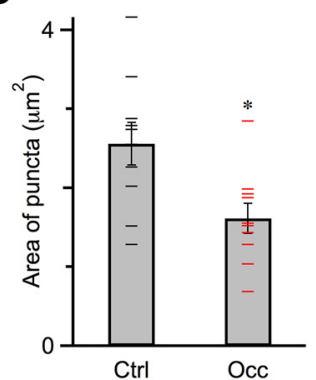

Figure 6. Endbulb structure changed after occlusion. $A$, Single optical sections of a control (P31, left) mouse and an occluded (P31, right) mouse immunolabeled for VGLUT1 (green). Scale bar, $10 \mu \mathrm{m} . \boldsymbol{B}$, Outlines of puncta for a control (left) and an occluded (right) mouse shown in $A$. C, Number of puncta surrounding BCs for control mice (10 cells) and occluded mice ( 10 cells). The number of puncta after occlusion was similar compared with control mice $(p>0.1)$. Error bars indicate mean \pm SEM. Circles indicate number of puncta for individual $B C s . D$, Average area of puncta surrounding $B C s$ for control mice (10 cells) and occluded mice (10 cells). Puncta significantly shrank after occlusion $(p<0.05)$. Error bars indicate mean \pm SEM. Line marks indicate average area of puncta for individual $\mathrm{BC}$ s. ${ }^{*} p<0.05$.

of $N, P_{\mathrm{r}}$, and $Q$ appropriately. Endbulb AMPARs show significant saturation (Chanda and Xu-Friedman, 2010), so for meanvariance analysis, the synaptic parameters we measured in the absence of a low-affinity antagonist likely relate to release sites rather than individual vesicles. Our mean-variance estimate of $N$ in control was $\sim 100$, which is on the same order as previous estimates of the number of release sites $(\sim 126)$ and is smaller than the estimated vesicle pool $(\sim 300)$ (Nicol and Walmsley, 2002; Mendoza Schulz et al., 2014). In addition, the estimate of $Q$ from mean-variance analysis $(\sim 120 \mathrm{pA})$ was larger than the mEPSC measured in voltage clamp $(\sim 100 \mathrm{pA})$. This is consistent with the mean-variance $Q$ reflecting the average quantal size of an entire release site, rather than the receptors activated by a single mEPSC.

The integration method also yields quantitative estimates of $N$ and $P_{r}$, but these values must be interpreted differently. Kynurenate was used in these experiments to prevent postsynaptic receptor saturation, so the value of $P_{\mathrm{r}}$ should relate to individual vesicles rather than release sites. Also, because kynurenate blocks the majority of AMPA receptors, $Q$ is difficult to measure and, therefore, $N$ cannot be converted to the number of releasable vesicles.
A

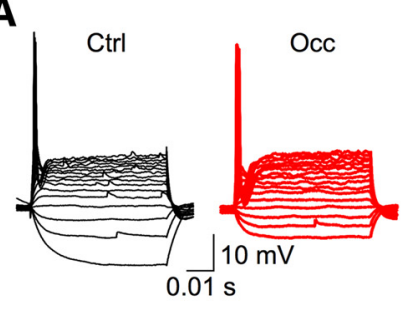

C

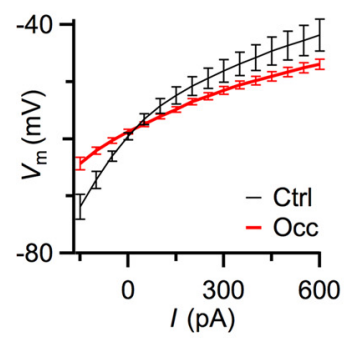

$\mathbf{E}_{100 \mathrm{~Hz}}$

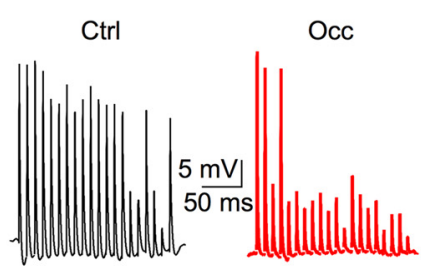

$\mathbf{F} 200 \mathrm{~Hz}$

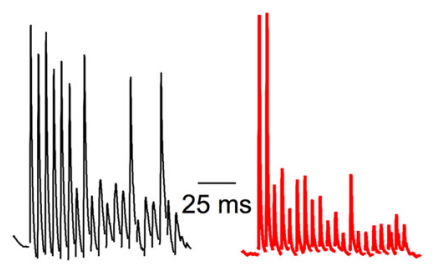

G
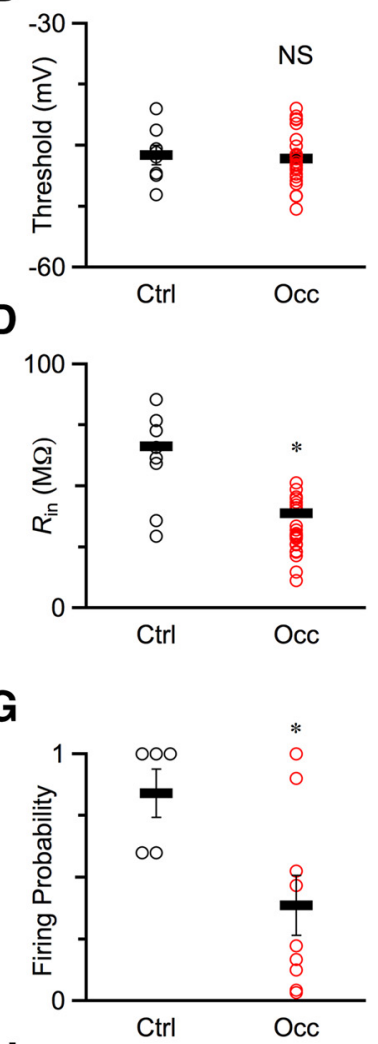

H

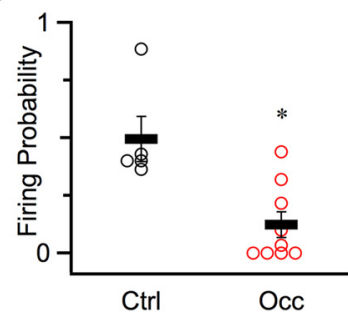

Figure 7. $B C$ excitability decreased after occlusion. $\boldsymbol{A}$, Representative current-clamp traces recorded from a P20 control (left) mouse and a P23 occluded (right) mouse in response to current injection. B, Spike thresholds for control (8 cells) and occluded (24 cells) mice. Open circles represent raw data. Line markers indicate average results for control and occlusion. There were no significant changes in threshold $(p>0.5)$. C, Average plots of voltage versus injected current from control ( 8 cells) and occluded ( 24 cells) mice. $D$, Input resistances $\left(R_{\text {in }}\right)$ at $-60 \mathrm{mV}$ for control and occluded mice. $R_{\text {in }}$ significantly decreased after occlusion $(p<0.05)$. Line markers indicate mean \pm SEM. Open circles represent individual data points. $E, F$, Example traces of current-clamp recordings of control BCs (left) and occluded BCs (right) in response to fiber stimulation at $100 \mathrm{~Hz}(\boldsymbol{E})$ and $200 \mathrm{~Hz}(\boldsymbol{F})$. Strip chart plots of firing probability for both 100 $\mathrm{Hz}(\boldsymbol{G})$ and $200 \mathrm{~Hz}(\boldsymbol{H})$. Firing probability was calculated during the last 10 stimuli during the trains. Spike fidelity decreased significantly after occlusion $\left({ }^{*} p<0.05\right)$.

Bidirectional, experience-dependent, homeostatic mechanism at endbulbs

The effects of occlusion at endbulbs are likely related to the effects of exposure to constant noise (Ngodup et al., 2015). After noise exposure, endbulbs decreased $P_{\mathrm{r}}$ and increased $N$, and $\mathrm{BC}$ spiking was enhanced. Furthermore, neither occlusion nor noiseexposure led to changes in $\mathrm{EPSC}_{1}$ or $\mathrm{Q}$. In addition, $P_{\mathrm{r}}$ recovered to near-normal after noise-exposure and occlusion ceased. These parallels suggest that endbulbs optimize synaptic properties over a wide range of sound conditions using a single activitydependent, homeostatic mechanism. This presynaptic mechanism could be related to activity-dependent changes in $P_{\mathrm{r}}$ seen in 
hippocampal cell culture and the Drosophila neuromuscular junction (Frank et al., 2006; Branco et al., 2008). However, in those systems, changes take place within a few hours, which is much faster than at endbulbs.

Postsynaptic effects by contrast do not appear to be subject to a single mechanism. After occlusion, spike threshold remained constant and $R_{\text {in }}$ decreased, whereas after noise-rearing, spike threshold decreased and $R_{\text {in }}$ remained constant (Ngodup et al., 2015). A change in spike threshold could arise from changes in the axon initial segment (Grubb and Burrone, 2010; Kuba et al., 2010). A change in $R_{\text {in }}$ could occur through an increase in $\mathrm{K}$ channel expression (Barnes-Davies et al., 2004; Lu et al., 2004). Thus, changes in postsynaptic excitability may result from two separate, activity-dependent mechanisms.

\section{Accounting for normal variability in $P_{\mathbf{r}}$}

Our results may shed light on the regulation of $P_{\mathrm{r}}$ under normal sound conditions. In vitro, the amount of depression among endbulbs varies considerably (Yang and Xu-Friedman, 2009), and in vivo, auditory nerve fibers vary in their amount of activity (Kiang and Watanabe, 1965; Liberman, 1978). Experience-dependent changes of $P_{\mathrm{r}}$ may connect diversity in firing rate to $P_{\mathrm{r}}$ : low firing rate fibers would have higher $P_{\mathrm{r}}$, whereas high firing rate fibers would have lower $P_{\mathrm{r}}$. Spontaneous rate of auditory nerve fibers has been linked to synaptic morphology (Ryugo and Rouiller, 1988), with high-rate fibers having larger and more intricate structures. Furthermore, synaptic morphology correlates with $P_{\mathrm{r}}$ at the calyx of Held (Grande and Wang, 2011). This mechanism may also account for the fact that auditory nerve fibers that converge on the same $\mathrm{BC}$ have similar $P_{\mathrm{r}}$, but onto different $\mathrm{BCs}$ do not (Yang and Xu-Friedman, 2009, 2012), because fibers with similar firing rate appear to converge on the same BCs (Ryugo and Sento, 1991). Finally, our results add more evidence that $P_{\mathrm{r}}$ is functionally important, because it is difficult to understand why $P_{\mathrm{r}}$ would change in different activity conditions if it were not. Additional work will be needed to test how changes in $P_{\mathrm{r}}$ and $\mathrm{N}$ at endbulbs support auditory processing.

\section{References}

Barnes-Davies M, Barker MC, Osmani F, Forsythe ID (2004) Kvl currents mediate a gradient of principal neuron excitability across the tonotopic axis in the rat lateral superior olive. Eur J Neurosci 19:325-333. CrossRef Medline

Branco T, Staras K, Darcy KJ, Goda Y (2008) Local dendritic activity sets release probability at hippocampal synapses. Neuron 59:475-485. CrossRef Medline

Buran BN, Sarro EC, Manno FA, Kang R, Caras ML, Sanes DH (2014) A sensitive period for the impact of hearing loss on auditory perception. J Neurosci 34:2276-2284. CrossRef Medline

Cant NB, Benson CG (2003) Parallel auditory pathways: projection patterns of the different neuronal populations in the dorsal and ventral cochlear nuclei. Brain Res Bull 60:457-474. CrossRef Medline

Caras ML, Sanes DH (2015) Sustained perceptual deficits from transient sensory deprivation. J Neurosci 35:10831-10842. CrossRef Medline

Chanda S, Xu-Friedman MA (2010) A low-affinity antagonist reveals saturation and desensitization in mature synapses in the auditory brain stem. J Neurophysiol 103:1915-1926. CrossRef Medline

Clarkson C, Antunes FM, Rubio ME (2016) Conductive hearing loss has long-lasting structural and molecular effects on presynaptic and postsynaptic structures of auditory nerve synapses in the cochlear nucleus. J Neurosci 36:10214-10227. CrossRef Medline

Connelly CJ, Ryugo DK, Muniak MA (2016) The effect of progressive hearing loss on the morphology of endbulbs of Held and bushy cells. Hear Res. Advance online publication. Retrieved Jul. 26, 2016. doi: 10.1016/j.heares.2016.07.004. CrossRef Medline

de Villers-Sidani E, Merzenich MM (2011) Lifelong plasticity in the rat auditory cortex: basic mechanisms and role of sensory experience. Prog Brain Res 191:119-131. CrossRef Medline
Foster KA, Regehr WG (2004) Variance-mean analysis in the presence of a rapid antagonist indicates vesicle depletion underlies depression at the climbing fiber synapse. Neuron 43:119-131. CrossRef Medline

Frank CA, Kennedy MJ, Goold CP, Marek KW, Davis GW (2006) Mechanisms underlying the rapid induction and sustained expression of synaptic homeostasis. Neuron 52:663-677. CrossRef Medline

Gates GA (1996) Cost-effectiveness considerations in otitis media treatment. Otolaryngol Head Neck Surg 114:525-530. CrossRef Medline

Grande G, Wang LY (2011) Morphological and functional continuum underlying heterogeneity in the spiking fidelity at the calyx of Held synapse in vitro. J Neurosci 31:13386-13399. CrossRef Medline

Grande G, Negandhi J, Harrison RV, Wang LY (2014) Remodelling at the calyx of Held-MNTB synapse in mice developing with unilateral conductive hearing loss. J Physiol 592:1581-1600. CrossRef Medline

Gravel JS, Wallace IF (2000) Effects of otitis media with effusion on hearing in the first 3 years of life. J Speech Lang Hear Res 43:631-644. CrossRef Medline

Gravel JS, Roberts JE, Roush J, Grose J, Besing J, Burchinal M, Neebe E, Wallace IF, Zeisel S (2006) Early otitis media with effusion, hearing loss, and auditory processes at school age. Ear Hear 27:353-368. CrossRef Medline

Grubb MS, Burrone J (2010) Activity-dependent relocation of the axon initial segment fine-tunes neuronal excitability. Nature 465:1070-1074. CrossRef Medline

Harris JA, Rubel EW (2006) Afferent regulation of neuron number in the cochlear nucleus: cellular and molecular analyses of a critical period. Hear Res 216:127-137. Medline

Henry KR (1967) Audiogenic seizure susceptibility induced in C57b1/6j mice by prior auditory exposure. Science 158:938-940. CrossRef Medline

Holm VA, Kunze LH (1969) Effect of chronic otitis media on language and speech development. Pediatrics 43:833-839. Medline

Keck T, Keller GB, Jacobsen RI, Eysel UT, Bonhoeffer T, Hübener M (2013) Synaptic scaling and homeostatic plasticity in the mouse visual cortex in vivo. Neuron 80:327-334. CrossRef Medline

Kiang NY, Watanabe T (1965) Discharge patterns of single fibers in the cat's auditory nerve. Cambridge, MA: Massachusetts Institute of Technology.

Kopp-Scheinpflug C, Tempel BL (2015) Decreased temporal precision of neuronal signaling as a candidate mechanism of auditory processing disorder. Hear Res 330:213-220. CrossRef Medline

Kuba H, Oichi Y, Ohmori H (2010) Presynaptic activity regulates $\mathrm{Na}(+)$ channel distribution at the axon initial segment. Nature 465:1075-1078. CrossRef Medline

Kuba H, Adachi R, Ohmori H (2014) Activity-dependent and activityindependent development of the axon initial segment. J Neurosci 34: 3443-3453. CrossRef Medline

Lauer AM, Connelly CJ, Graham H, Ryugo DK (2013) Morphological characterization of bushy cells and their inputs in the laboratory mouse (mus musculus) anteroventral cochlear nucleus. PLoS One 8:e73308. CrossRef Medline

Liberman MC (1978) Auditory-nerve response from cats raised in a lownoise chamber. J Acoust Soc Am 63:442-455. CrossRef Medline

Limb CJ, Ryugo DK (2000) Development of primary axosomatic endings in the anteroventral cochlear nucleus of mice. J Assoc Res Otolaryngol 1:103-119. CrossRef Medline

Lorente de Nó R (1981) The primary acoustic nuclei. New York: Raven.

Lu Y, Monsivais P, Tempel BL, Rubel EW (2004) Activity-dependent regulation of the potassium channel subunits Kv1.1 and Kv3.1. J Comp Neurol 470:93-106. CrossRef Medline

Mendoza Schulz A, Jing Z, Sánchez Caro JM, Wetzel F, Dresbach T, Strenzke N, Wichmann C, Moser T (2014) Bassoon-disruption slows vesicle replenishment and induces homeostatic plasticity at a CNS synapse. EMBO J 33:512-527. CrossRef Medline

Mowery TM, Kotak VC, Sanes DH (2015) Transient hearing loss within a critical period causes persistent changes to cellular properties in adult auditory cortex. Cereb Cortex 25:2083-2094. CrossRef Medline

Ngodup T, Goetz JA, McGuire BC, Sun W, Lauer AM, Xu-Friedman MA (2015) Activity-dependent, homeostatic regulation of neurotransmitter release from auditory nerve fibers. Proc Natl Acad Sci U S A 112:6479_ 6484. CrossRef Medline

Nicol MJ, Walmsley B (2002) Ultrastructural basis of synaptic transmission between endbulbs of Held and bushy cells in the rat cochlear nucleus. J Physiol 539:713-723. CrossRef Medline

O’Brien RJ, Kamboj S, Ehlers MD, Rosen KR, Fischbach GD, Huganir RL 
(1998) Activity-dependent modulation of synaptic AMPA receptor accumulation. Neuron 21:1067-1078. CrossRef Medline

Oertel D (1983) Synaptic responses and electrical properties of cells in brain slices of the mouse anteroventral cochlear nucleus. J Neurosci 3:20432053. Medline

Oertel D (1999) The role of timing in the brain stem auditory nuclei of vertebrates. Annu Rev Physiol 61:497-519. CrossRef Medline

Oleskevich S, Walmsley B (2002) Synaptic transmission in the auditory brainstem of normal and congenitally deaf mice. J Physiol 540:447-455. CrossRef Medline

O’Neil JN, Connelly CJ, Limb CJ, Ryugo DK (2011) Synaptic morphology and the influence of auditory experience. Hear Res 279:118-130. CrossRef Medline

Polley DB, Thompson JH, Guo W (2013) Brief hearing loss disrupts binaural integration during two early critical periods of auditory cortex development. Nat Commun 4:2547. CrossRef Medline

Popescu MV, Polley DB (2010) Monaural deprivation disrupts development of binaural selectivity in auditory midbrain and cortex. Neuron 65:718-731. CrossRef Medline

Ryugo DK, Fekete DM (1982) Morphology of primary axosomatic endings in the anteroventral cochlear nucleus of the cat: a study of the endbulbs of Held. J Comp Neurol 210:239-257. CrossRef Medline

Ryugo DK, Rouiller EM (1988) Central projections of intracellularly labeled auditory nerve fibers in cats: morphometric correlations with physiological properties. J Comp Neurol 271:130-142. CrossRef Medline

Ryugo DK, Sento S (1991) Synaptic connections of the auditory-nerve in cats: relationship between endbulbs of Held and spherical bushy cells. J Comp Neurol 305:35-48. CrossRef Medline

Schmiedt RA, Mills JH, Boettcher FA (1996) Age-related loss of activity of auditory-nerve fibers. J Neurophysiol 76:2799-2803. Medline

Schneggenburger R, Meyer AC, Neher E (1999) Released fraction and total size of a pool of immediately available transmitter quanta at a calyx synapse. Neuron 23:399-409. CrossRef Medline

Silver RA (2003) Estimation of nonuniform quantal parameters with multiple-probability fluctuation analysis: theory, application and limitations. J Neurosci Methods 130:127-141. CrossRef Medline

Skoe E, Krizman J, Anderson S, Kraus N (2015) Stability and plasticity of auditory brainstem function across the lifespan. Cereb Cortex 25:14151426. CrossRef Medline

Smith PH, Joris PX, Yin TC (1993) Projections of physiologically characterized spherical bushy cell axons from the cochlear nucleus of the cat: evidence for delay lines to the medial superior olive. J Comp Neurol 331: 245-260. CrossRef Medline

Song P, Yang Y, Barnes-Davies M, Bhattacharjee A, Hamann M, Forsythe ID, Oliver DL, Kaczmarek LK (2005) Acoustic environment determines phosphorylation state of the Kv3.1 potassium channel in auditory neurons. Nat Neurosci 8:1335-1342. CrossRef Medline

Sun W, Lu J, Stolzberg D, Gray L, Deng A, Lobarinas E, Salvi RJ (2009) Salicylate increases the gain of the central auditory system. Neuroscience 159:325-334. CrossRef Medline

Sun W, Manohar S, Jayaram A, Kumaraguru A, Fu Q, Li J, Allman B (2011) Early age conductive hearing loss causes audiogenic seizure and hyperacusis behavior. Hear Res 282:178-183. CrossRef Medline

Takesian AE, Kotak VC, Sanes DH (2010) Presynaptic GABA(B) receptors regulate experience-dependent development of inhibitory short-term plasticity. J Neurosci 30:2716-2727. CrossRef Medline

Thanawala MS, Regehr WG (2013) Presynaptic calcium influx controls neurotransmitter release in part by regulating the effective size of the readily releasable pool. J Neurosci 33:4625-4633. CrossRef Medline
Thanawala MS, Regehr WG (2016) Determining synaptic parameters using high-frequency activation. J Neurosci Methods 264:136-152. CrossRef Medline

Thornton JL, Chevallier KM, Koka K, Lupo JE, Tollin DJ (2012) The conductive hearing loss due to an experimentally induced middle ear effusion alters the interaural level and time difference cues to sound location. J Assoc Res Otolaryngol 13:641-654. CrossRef Medline

Tucci DL, Rubel EW (1985) Afferent influences on brain stem auditory nuclei of the chicken: effects of conductive and sensorineural hearing loss on n. magnocellularis. J Comp Neurol 238:371-381. CrossRef Medline

Tucci DL, Born DE, Rubel EW (1987) Changes in spontaneous activity and CNS morphology associated with conductive and sensorineural hearing loss in chickens. Ann Otol Rhinol Laryngol 96:343-350. CrossRef Medline

Turrigiano GG, Nelson SB (2004) Homeostatic plasticity in the developing nervous system. Nat Rev Neurosci 5:97-107. CrossRef Medline

Turrigiano GG, Leslie KR, Desai NS, Rutherford LC, Nelson SB (1998) Activity-dependent scaling of quantal amplitude in neocortical neurons. Nature 391:892-896. CrossRef Medline

Wang H, Yin G, Rogers K, Miralles C, De Blas AL, Rubio ME (2011) Monaural conductive hearing loss alters the expression of the GluA3 AMPA and glycine receptor alphal subunits in bushy and fusiform cells of the cochlear nucleus. Neuroscience 199:438-451. CrossRef Medline

Wang J, Ding D, Salvi RJ (2002) Functional reorganization in chinchilla inferior colliculus associated with chronic and acute cochlear damage. Hear Res 168:238-249. CrossRef Medline

Wang Y, Manis PB (2005) Synaptic transmission at the cochlear nucleus endbulb synapse during age-related hearing loss in mice. J Neurophysiol 94:1814-1824. CrossRef Medline

Whitton JP, Polley DB (2011) Evaluating the perceptual and pathophysiological consequences of auditory deprivation in early postnatal life: a comparison of basic and clinical studies. J Assoc Res Otolaryngol 12:535547. CrossRef Medline

Wright S, Hwang Y, Oertel D (2014) Synaptic transmission between end bulbs of Held and bushy cells in the cochlear nucleus of mice with a mutation in Otoferlin. J Neurophysiol 112:3173-3188. CrossRef Medline

Wu SH, Oertel D (1984) Intracellular injection with horseradish peroxidase of physiologically characterized stellate and bushy cells in slices of mouse anteroventral cochlear nucleus. J Neurosci 4:1577-1588. Medline

Xu H, Kotak VC, Sanes DH (2007) Conductive hearing loss disrupts synaptic and spike adaptation in developing auditory cortex. J Neurosci 27: 9417-9426. CrossRef Medline

Yang H, Xu-Friedman MA (2008) Relative roles of different mechanisms of depression at the mouse endbulb of Held. J Neurophysiol 99:2510-2521. CrossRef Medline

Yang H, Xu-Friedman MA (2009) Impact of synaptic depression on spike timing at the endbulb of Held. J Neurophysiol 102:1699-1710. CrossRef Medline

Yang H, Xu-Friedman MA (2012) Emergence of coordinated plasticity in the cochlear nucleus and cerebellum. J Neurosci 32:7862-7868. CrossRef Medline

Yang Y, Xu-Friedman MA (2015) Different pools of glutamate receptors mediate sensitivity to ambient glutamate in the cochlear nucleus. J Neurophysiol 113:3634-3645. CrossRef Medline

Yen JC, Chang FJ, Chang S (1995) A new criterion for automatic multilevel thresholding. IEEE Trans Image Process 4:370-378. CrossRef Medline

Zhou F, Shefer A, Kong Y, Nuorti JP (2008) Trends in acute otitis mediarelated health care utilization by privately insured young children in the United States, 1997-2004. Pediatrics 121:253-260. CrossRef Medline 